\title{
Enhancing Entrepreneurship Education in Ordinary Secondary Schools to develop Employment opportunity: A case of Kinondoni District Dar Es Salaam -Tanzania
}

\author{
Cleopa Soi, Demetria Gerold Mkulu \\ Department of Educational foundation, St. Augustine University of Tanzania, Dar Centre \\ cleopaesoi@gmail.com
}

Received: 27 Dec 2021; Received in revised form: 10 Feb 2022; Accepted: 19 Feb 2022 (C)2022 The Author(s). Published by TheShillonga. This is an open access article under the CC BY license (https://creativecommons.org/licenses/by/4.0/)

\begin{abstract}
This study aimed to enhance entrepreneurship education toward preparing secondary school students at Kinondoni District Dar es salaam in Tanzania for the creation of employment opportunities. The study aimed at assessing the roles of Entrepreneurship Education in developing employment opportunities for ordinary level secondary schools. The study employed a mixed-method design in examining these phenomena. One hundred and nineteen (119) participants were conveniently sampled and heads of schools were interviewed within 6 weeks. Questionnaires and interview guides were used to collect data hence quantitative data were analyzed descriptively with the aid of SPSS version 22. All qualitative data obtained in the study were thematically analyzed. The study found that Entrepreneurship Education is a very crucial as it prepares student to be good citizens. Also, in today's environment of unpredictability, dynamic job market, and new technologies, are progressing with each passing day and the current generation is progressing towards a future without any inevitability. They might take years to master a particular trade or skill but with time it might disappear from the market, therefore destroying students' careers. The study concluded that teaching entrepreneurship as a study in education has to move beyond listing strategies for raising capital. Students need also to be equipped with skills enabling them to deal with negative attitudes, competition from cheap imports, and the choice of appropriate technologies. There is a distinguished need to improve training programs and make changes in the education system in Tanzania; there is also a need to develop entrepreneurs who would be able to navigate through local troubled waters.
\end{abstract}

Keywords-entrepreneurship education, job employment.

I. INTRODUCTION AND BACKGROUND TO THE STUDY

Success of an individual or society is not the results of taking one good choice or step. Really success requires planning of strategy after strategy and commitment to the planned strategies. Failing to have a strategy plan leads to emergency of challenges. A review of literature have identified how entrepreneurship education is vital to the social and economic development of an individual and society as a whole. However, the provision of entrepreneurship education has been minimal, little is taught theoretically but not linked to practical (Muhura, 2013). Nevertheless, some students engage in entrepreneurship after graduating just to overcome economic challenges. Aluwong, (2010) claimed that there are some limitations to this such as poor capital and training which prohibit the progress of entrepreneurs. In
Tanzania, entrepreneurs do not have proper formal training and most are based on informal training within the environment by imitating people practicing entrepreneurship. Gangi (2015), entrepreneurship education is one of the faster-growing fields of education; it is considered as a solution for global competition and job creation. It is obvious that most stakeholders view entrepreneurship in terms of its economic roles, which are centered on new ventures creation, which in turn create jobs, intensify competition, and may even increase productivity. Kuratko (2015) suggests that entrepreneurship is concerned with the mindset that views new venture creation as a focal aspect of entrepreneurship. Students should be well prepared by teachers to enter into new venture creations which enable them to understand and utilize all business opportunities within their local environment. 
Entrepreneurship education on its broad meaning seeks to promote and provide learners with skills, attitude knowledge, and motivation for entrepreneurial success in a different aspect. Entrepreneurship education has the power to equip the young generation with function and skills and knowledge to build up their traits, attitudes, and vision (European Union, 2006). The economic development of many nations we see today has reached high development because of entrepreneurship. China at large is a clear good example of impressive economic development which was a result of the promotional of entrepreneurship from glass roots and put a strategic plan in the school curriculum, so students learn entrepreneurship education from elementary school to university level. It's normal to find a Chinese aged creating a mobile phone or any device in communication, while in Africa University students can't do such a thing because in Africa Entrepreneurship is less concerned with the education system. (Ruskovaara and Pihkala, 2015). Many people think that entrepreneurship just starting a business and making money. But there is a lot covered on it, it is more than that. Entrepreneurship is a unique way of people's life and mindset in which different people innovated and try to solve their daily problems and sometimes create value in the society, (Falck et al., 2016)

In Tanzania people look at entrepreneurship as "being matching guys" (MACHINGA), this gives out a wrong impression to students in school when introducing this matter, they forget that entrepreneurship is a driving force of restructuring an economy moving to a market economy. Entrepreneurship education is a form of training that prepares learners to be loyal, respected, responsible, and enterprising. It helps learners to develop skills, knowledge, and attitudes necessary to achieve the target goals set out for themselves. People with entrepreneurship are indeed more employed because of their different skills gained. In other countries across the world such as Finland, pre services training for teachers and the country's education providers are essential to developing entrepreneurship skills among students, (Clement, 2016).

From the above stated standing points, it should be well known that the transformation of education today to reflect the current global demand for entrepreneurship skills is inevitable. Maina, (2014), students' demand for entrepreneurship education is said to be a result of changing the structure of the economy, downsizing by larger companies, changing business patterns, movement to different markets, and increasing policy attention. According to Henderson and Robertson (2000), in the study of entrepreneurship for self-employment, report that Entrepreneurship education will enhance students' and school levers to learn entrepreneurial capacities to overcome the problem of unemployment and ability to utilize economic opportunities in the society. Njorege and Gathungu (2013) in the study of the effect of Entrepreneurship Education and Training on the development of small and medium found that in Africa, the key to the success of implementing entrepreneurship education is through education and training that depend on state learners. Some of the African countries such as Nigeria entrepreneurship Education has become a compulsory course for all students in basic education by considering the student's area of specialization (Babatope, 2011)

Entrepreneurship education in Tanzania is not new but has a long history in the education system since 1967 during education for self-reliance. During that time, all levels of education, especially primary education focused on molding young people ready for productive activities, especially in the agricultural sector (Maina, 2014). Some of the policies developed in the country to promote the adoption of entrepreneurship education skills include; -The National Higher Education Policy of 1999 focus on producing graduates who could be able to cope with the changes of demand of the labor market by equipped with entrepreneurship education (URT, 1999). SME Policy (2003) where focus on self-employment ideas based on employment creation in collaboration with National Economic empowerment policy, 2004 which focus on broad E-skills, Tanzania Institute of Education (TIE), Tanzania Commission for University (TCU), and National Employment Policy, 2008 all focus on employability skills among graduates as well as the proposed link between government and education institution. The recent Education and Training Policy (2014) focuses on promoting the Education for Selfreliance philosophy (URT, 2014). Furthermore, Muhura, (2013), explain the low levels of entrepreneurship skills for graduate and university as well colleges are blamed to produce more job seekers than job creators. URT, (2003) suggests that entrepreneurship enables them to face the competition of starting their firms.

In exploring the gap in policy aspect in Tanzania, entrepreneurship as a skill is not well addressed. When you read the Higher Education Policy of 1999, it emphasizes also the need for training institutions to review their curriculum so that they integrate the teaching of entrepreneurship (URT, 1999a). Even a reform of the Education policy of 1995 to the current policy of 2014 was expected to come out with entrepreneurship education as one of the core points among the solutions for job employment creation, but it is not clear. Therefore, the study will assess how entrepreneurship education will help students in the creation of employment opportunities and address some of the challenges and a way forward in 
enhancing employment creation opportunities for ordinary level secondary schools students as outlined on the school curriculum. The objective of this study is sought to assess the roles of Entrepreneurship Education in developing employment opportunities for students

\section{LITERATURE REVIEW AND THEORETICAL FRAMEWORK OF THE STUDY}

This study employed Social Development Theory of learning under the constructivism paradigm. The theory was originated by Lev Vygotsky, a Russian psychologist who lived 1896-1934 during Russian Revolution. His work was published in 1962 (Newman and Holzman, 2013). Constructivism learning paradigm posits that learning is an active, contextualized process of constructing knowledge rather than acquiring it. Constructivists include Vygotsky, Piaget, Dewey, Vico, Rorty \& Bruner. They believe that knowledge is constructed based on individual experiences and hypothesis of the environment. Learners continue to test these hypotheses through social negotiation. Each person has a different interpretation and construction of knowledge. The learner is not a blank slate but brings past experiences and cultural factors to a learning situation (Newman and Holzman, 2013). Vygotsky theory was an attempt to explain consciousness as the product of socialization. For example; in the learning of language, our first utterances with peers or adults are for the purpose of communication but once mastered they become internalized and allow ' inner speech.' Vygotsky believed that speech and writing are tools developed from the culture to mediate social environment. These tools first help children to communicate their needs and later to develop higher order thinking skills. Constructivists posit that learning and human development are richly collared by social and cultural context in which people find themselves. Ethnicity, social class, gender, family life, history, self-concept, and the learning situation all influence an individual perception, thoughts, emotions, interpretation, and responses to information experience. The theory is holistic on the source of knowledge which leads to cognitive development. 'More knowledgeable other' who include the teachers, parents, peers, machines, and any other individual with more knowledge who as sources of knowledge. The theory also recognizes that a learner is not a blank slate and brings past experiences and cultural factors into learning situation (Newman and Holzman, 2013). Apart from classroom experiences, home experiences, community experiences and other out of classroom experiences all play a part in how a child acquires literacy and numeracy skills. The theory gives suggestions on how educators can impart skills for example through collaborative learning and scaffolding. This theory advocates collaborative learning suggesting that group members should have various levels of ability for the less able learners to learn from the advanced peers. Since social interaction plays a fundamental role in the cognitive development process, the avenues of social interaction which include home and school environment should be consciously structured to promote learning from the ' more knowledgeable other' (Newman and Holzman, 2013). The teacher or more advanced peer can help to structure or arrange a task so that a pupil can work on it successfully. This theory also advocates collaborative learning suggesting that acquisition of literacy skills can be enhanced by grouping different ability learners so that advanced learners can help the less skilled learners.

\section{The roles of Entrepreneurship Education in developing employment opportunities}

Entrepreneurship education prepares the youths to be responsible and enterprising, Raposo and Paco (2011). In a similar vein, UNESCO (2008) viewed educational entrepreneurship as all kinds of experiences that give students the ability and vision of how to access and transform opportunities of different kinds. In essence, educational entrepreneurship provides a platform for youths to transform opportunities into business ventures and to manage those ventures to become a medium for job creation for themselves and others. Enu (2012) argues that the ultimate goal of educational entrepreneurship is all about increasing the student's ability to anticipate and respond to societal changes. In other words, through educational entrepreneurship, students are equipped to deploy their creativity ability for the good and benefits of the larger society. They are also empowered to take initiative, responsibilities, and risks. According to Brush (2014) and Kuratko (2005), entrepreneurship education within a school generally consists of a nested set of activities, including curriculum, curricular activities, and research efforts. In other words, the decisions around entrepreneurship education include everything from learning objectives, topics covered, selection of materials (including cases, exercises, and concepts), pedagogy, and delivery mechanisms Patricia et ' al (2010).

Lack of a sustainable environment and availability of resources may pose constraints that arguably may influence the development of entrepreneurial intentions (Reynolds et al. 2002).

Scholars highlight the role of hard and soft infrastructures, stronger institutions for tax and regulations, and easy access to finance may support entrepreneurial actions 
(Maina2014; Nwekeaku 2013; Ihugba, Odie, and Njoku 2014)

Kalmias (2004, 2016) assessment of the current state of entrepreneurial education is that the actual curricula still fall short of the prescriptions of the Framework, which may take years to fully implement. A leading problem in the implementation of the guidelines is the tradition of rote learning in many Tanzanian colleges (Kalmias and Herman, 2016). Gibb (2006) claims that rote learning is fundamentally at odds with building entrepreneurial attitudes among Tanzanian youth as it precludes the mastery of active engagement skills and assumes that independent thinking is inferior to absorbing already available information. This observation corresponds to Hytti and O'Gorman's (2004) that in order to improving entrepreneurship education and is one of the challenges the intervention they propose seeks to address.

As Tanzania's economy is still dominated by the industry and construction sectors -22.2 percent of GDP come from these sectors (National Bureau of Statistics, 2013), this education strategy is a rational response to currently-dominant economic conditions. However, in the future, Tanzania will likely need to shift from its dependency on foreign investment in industry, especially in areas such as the provision of local services where such investment falls short of addressing pressing issues. Mwasalwiba (2012), in his discussion of entrepreneurial attitudes in Tanzanian higher education, identifies the expectation placed by the system on graduates that the most prestigious and secure form of labor is salaried employment. Currently, a predominant cultural narrative is that being an entrepreneur equals not being able to find employment elsewhere. Salaried employment provides a relative measure of security of future income streams, which for many households, especially those who have invested substantial resources in the higher education of their children, is a priority.

As discussed previously, changing such attitude would necessarily involve a more holistic effort that involves not only educational authorities and curriculum designers but also the g ILO (2012) (11) Argues that one of the main reasons for the high unemployment across the world over is the growing mismatch between supply and demand of skills. Further, the report also notes that in some countries there is an excessive supply of skilled workers but a shortage of skilled jobs. This is the result of insufficient material for entrepreneurship education as well as pedagogical support from experts.

In Finland, entrepreneurship education is part and parcel of the core subject, in Nigeria youth are trained on how to utilize their natural resources such as in renewable energy technology and green, in Rwanda Entrepreneurship education, is a core subject, but not the same as Tanzania. Kalema, 2018 argues that self-reliance education is a core subject in Tanzania's curriculum but due to the reformation of the national curriculum now is not. Many scholars give their views towards entrepreneurship and employment creation. Hytti and O' Gorman (2004) in their assessment of entrepreneurship education and its role in the development process, claim that entrepreneurship education considered as an intervention should seek to achieve three main goals which include creating awareness of entrepreneurship, the opportunities for engaging and profitable work it offers, and the good it could do for society. Although it is often assumed that many young people have positive attitudes towards starting their own business and working on their terms. The Entrepreneur education benefits the students in decision making. For example, in university-level Economics classes, entrepreneurship simulation software could be used to expose students to the decision-making process involved in a business (Chiraka et al, 2013). Hytti and O'Gorman (2004), suggest that Entrepreneurship Education should be the core pedagogical component that helps to change their attitudes, ideas, and skills and what they can do for employment creation in Tanzania. Yagoub (2013) recommended that educational leaders in developing countries should have to develop the integration of students' self-reliance and self-business programs in the education policy with self-employment topics in every program across all levels to ensure all youth in the country get self-employment intention developed. Ajayi \& Ademokun (2010) seek to investigate the impact of entrepreneurship training and the availability of ancillary credit using a combination of qualitative and quantitative data.

\section{METHODOLOGY}

The study adopted a mixed research approach embracing qualitative and quantitative approaches. The target population of this study includes 2350 education stakeholders comprised into five (06) categories of the unit like, District Education Officer (DEO), Heads of Schools, Teachers, and Students from this population is where the sample size was $\mathbf{1 1 9}$ participants. This study integrates both probability and non-probability techniques. Stratified sampling, a simple random sampling procedure, on the other hand, was used to select teachers and students to represent the entire population of the study. Therefore, a non-probability sampling participant has no chance to be selected in the study and the research was adopt purposive 
sampling which does not give chance to every individual to be selected.

\section{FINDINGS}

The study found that the benefit of entrepreneurship includes promoting creativity; enhancing unity, cooperation and employment opportunities. Furthermore, it should be taught as a separate subject that gives essential life skills such as the innovative approach to solving realworld problems, or as a topic in Civics to be taught as part of that subject. So, having entrepreneurship as a subject will enhance learners' employment creation skills.

In today's environment of unpredictability, dynamic job markets and new technologies are progressing with each passing day and the current generation is progressing towards a future without any inevitability. They might take years to master a particular trade or skill but with time it might disappear from the market, therefore destroying students' careers.

Table 1 How Entrepreneurship Education is taught in the class $(n=81)$

\begin{tabular}{lll}
\hline Statement & Respondents & Percentage \\
\hline Is taught as separate subject & 10 & $1.2 .3 \%$ \\
Is intergrated in subject because of curriculum & 31 & $38.2 \%$ \\
Is not taught at al & 25 & $30.8 \%$ \\
It is in science subjects & 15 & $18.5 \%$
\end{tabular}

Total number of respondents

Source:Survey Data, 2021.

Table 1 shows that about 38.2 percent of all respondents proved that entrepreneurship education is integrated into the subject because of the curriculum when compared to Finland, Japan, and China, to the entrepreneurship is part and parcel of the school curriculum and, is mandatory to be taught by all learners for their national development, also the scanner with Nigeria and Ghana in West Africa. On other hand, 30.8 percent of teachers proclaim that Entrepreneurship Education is very important even though is not taught as a subject rather than integrated into another subject. It was revealed during the analysis of the data that about 100 percent of heads of schools who were interviewed also agree that, Entrepreneurship Education is a fundamental subject but ignored to be taught as a separate subject, Elders once says," He who does not know one thing knows another" here they mean that when we think that students are not knowing things, it's not true they know a lot. During the interview one of the school head(s) explained;

“ Entrepreneurship education has arisen out as a demanding subject to be mastered by Tanzania Students despite their age. With each passing day, as the works are getting inadequate owing to numerous reasons such as technological advancements and population growth, the entrepreneurship option can be seen as a noteworthy carrier option among the current generation. Contributing suggestively to economic growth, entrepreneurship also generates plentiful job perceptive. As a result of which, the government should be understood that the young generation has to be encouraged to be motivated in so-called Entrepreneurship education, (Interviewee B July 2021).

This findings implies that entrepreneurship education is very crucial hence, it has to be adopted in all secondary schools in Tanzania so that learners could graduate with knowledge and skills, which would enable them to employ themselves. Looking at the situation of graduates nowadays they complete their education without skills. 
Table 2 Entrepreneurship education activities within the school $(n=119)$

\begin{tabular}{|c|c|c|c|c|c|}
\hline Statement & Never & $\begin{array}{l}\text { Several } \\
\text { times }\end{array}$ & $\begin{array}{l}\text { At least } \\
\text { a week }\end{array}$ & everyday & Once per month \\
\hline Topic on entrepreneurship & 0 & 35 & 10 & 5 & 10 \\
\hline Doing practical works & 10 & 2 & 2 & 0 & 15 \\
\hline Extra-curricular & 3 & 12 & 5 & 10 & 30 \\
\hline To raise the level of awareness & 0 & 5 & 5 & 10 & 35 \\
\hline Integrative and reflections learning & 0 & 10 & 15 & 15 & 20 \\
\hline New venture creation & 0 & 5 & 10 & 15 & 30 \\
\hline Project or young enterprise & 40 & 0 & 5 & 5 & 10 \\
\hline Producing and selling products & 60 & 0 & 0 & 0 & 0 \\
\hline $\begin{array}{lll}\text { Students } & \text { companies } & \text { playing } \\
\text { experiment } & & \end{array}$ & 60 & 0 & 0 & 0 & 0 \\
\hline Inculcate entrepreneurship behavior & 20 & 20 & 15 & 3 & 2 \\
\hline $\begin{array}{l}\text { Role models for students in } \\
\text { entrepreneurship }\end{array}$ & 2 & 30 & 20 & 4 & 4 \\
\hline Entrepreneurship spirit & 0 & 10 & 10 & 15 & 25 \\
\hline Entrepreneurship competences & 55 & 2 & 2 & 1 & 0 \\
\hline $\begin{array}{l}\text { Practical entrepreneurship } \\
\text { organization small venture }\end{array}$ & 50 & 1 & 2 & 3 & 4 \\
\hline Economic activities & 2 & 2 & 16 & 0 & 40 \\
\hline Financial management skills & 35 & 5 & 5 & 5 & 10 \\
\hline
\end{tabular}

Source: Survey Data, 2021.

Table 3 shows several topics teachers perform on entrepreneurship at least per week that makes 35 percent of practices compared to theoretical teaching. Creativity and innovation, the extra curriculum also is practice is some encompassing in some schools, hence entrepreneurship education generally is taught below the average and it needs to be taught as a separate subject from elementary school to University level to compete with other countries in socio-economic development in the world.

An Interview with participants one of the respondents commented that:

As teachers, we always try our level best to teach this young generation about entrepreneurship skills, we must understand that education should be for liberation and not for show off, learners have to come to senses that employment is an opportunity if we build the strong foundation to students concerning selfemployment we can rich to our goals instead of waiting for a color job (Interviewee A, June 2021)

\section{The role of Entrepreneurship Education for employment opportunities creation for ordinary secondary schools' students.}

The drive force of this study also is to find out about employment opportunities creation for ordinary secondary schools' students. It was found out by the researcher that; Entrepreneurship education allows students to study and creates an interdisciplinary environment to work and develop in. When interviewed school heads, students and District Education commented that, they prepare students for uncertain future and make the world a better place. When responding to the question one of school head in school X commented that;

"Deep down our soul we know that the jobs once existed decades ago, are nowhere to be found in the present situation. In the unpredictable and dynamic market, modern technologies are progressing in each passing day and the current generation is progressing towards a future without any inevitability. They might take years to master a particular trade or skills but with time it might disappear from the market resulting in 
destruction in student's careers. By learning about entrepreneurship, one door will always be open for venturing into if the things do not turn out as anticipated."

Another head of school D when interviewed she said, many scholars that students be left free to find their calling through it. Teachers should also be provided guidelines to manage students and help them to foster a pleasant environment for students to grow."

Teaching entrepreneurship skills through school is a process and it is highly recommended by

Table 4. 1: How often do you do the following entrepreneurship education activities within the school?

\begin{tabular}{llllll}
\hline Statement & Never & $\begin{array}{l}\text { Several } \\
\text { times }\end{array}$ & $\begin{array}{l}\text { At least } \\
\text { a week }\end{array}$ & $\begin{array}{l}\text { everyday } \\
\text { Once per } \\
\text { month }\end{array}$ \\
\hline Topic on entrepreneurship & 0 & 35 & 10 & 5 & 10 \\
Doing practical works & 10 & 2 & 2 & 0 & 15 \\
Extra-curricular & 3 & 12 & 5 & 10 & 30 \\
To raise the level of awareness & 0 & 5 & 5 & 10 & 35 \\
Integrative and reflections learning & 0 & 10 & 15 & 15 & 20 \\
New venture creation & 0 & 5 & 10 & 15 & 30 \\
Project or young enterprise & 40 & 0 & 5 & 5 & 10 \\
Producing and selling products & 60 & 0 & 0 & 0 & 0 \\
Students' companies playing & 60 & 0 & 0 & 0 & 0 \\
experiment & & & & & 2 \\
Inculcate entrepreneurship behavior & 20 & 20 & 15 & 3 & 4 \\
Role models for students in & 2 & 30 & 20 & 4 & 4 \\
entrepreneurship & & 10 & 10 & 15 & 25 \\
Entrepreneurship's spirit & 0 & 2 & 2 & 1 & 0 \\
Entrepreneurship's competences & 55 & 1 & 2 & 3 & 4 \\
Practical entrepreneurship & 50 & & & & 40 \\
organization small venture & & 5 & 16 & 0 & 10 \\
Economic activities & 2 & 55 & 5 & \\
Financial management skills & 35 & 5 & & & \\
\hline
\end{tabular}

Source: Survey Data, 2021.

Table 4.11show that, teachers do topic on entrepreneurship several times, they do practice at least a week that makes $35 \%$ of practices compared to theoretical teaching. Creativity and innovation, extra curriculum also is practice is some encompassing in some schools; hence entrepreneurship education is taught below the average and it need to be taught as a separate subject from elementary school to university level to competent with other countries in socio economic development in the world.

In Interview other Head of school was quoted,

"As teachers we always try our level best to teach this young generation about entrepreneurship skills, we must understand that, education should be for liberation and not for show off, learners have to come to senses that employment is an opportunity if we build the solid foundation to students concerning selfemployment, we can rich to our goals instead of waiting a colour job ...."

Students were asked by the researcher on topic that contains Entrepreneurship Education. About 85 were able to mention topics and explained why such topics related to entrepreneurship. Also, teachers were asked the same question and provided the relevant answers to students. 
Table 4.8.Topics Mentioned by students that they relate to entrepreneurship

\begin{tabular}{llll}
\hline S/N & Topic & Subject & Class/Form \\
\hline 1 & Organic & Chemistry (Mentioned by 12 students) & Form Four. \\
2. & Mining & Geography (Mentioned by 15 students) & Form Four \\
3 & Electrostatics & Physics (Mentioned by 10 students) & Form Three \\
4 & Historia ya Lugha ya Kiswahili & Kiswahili (Mentioned by 12 students & Form Three \\
5 & Population and Development & Geography (Mentioned by 8 students) & Form Three \\
6 & Chemical Formulae and & Chemistry (Mentioned by 10 students) & Form Four \\
& Equation & & \\
7 & Genres of Literature & Literature (Mentioned by 9 students) & Form 3and 4 \\
8 & Industries & Civics (Mentioned by 5 students) & Form 2 \\
9. & None Trading Organization & Bookkeeping (Mentioned by 15 students) & Form Four \\
10. & Tourism and Life skills & Civics (Mentioned by 80 students) &
\end{tabular}

\section{Source: Field study, 2021.}

Table 4.13, shows the topic that are related with entrepreneurship mentioned by students. This proved that even students have some sense of entrepreneurship education despite of being an independent subject.

The researcher asked the students on how the mention topics related to entrepreneurship skills.

Student X when asked about " How Organic in Chemistry related to entrepreneurship education?" He replied that;

"Tumejifunza kutengeneza, sabuni, dawa na hata mbolea za asili sasa huoni ushahidi tosha wa uhusiano wahi imadana ujasiliamali (We learn how to prepare alcohol, soap making, fertilizers for agriculture this real proved the relationship between Organic topic and entrepreneurship)"

Responding to the question "Can you relate any topic from Book-keeping and Entrepreneurship?" during focused group discussion, another student Y said;

"Yes, book-keeping plays a key role in Entrepreneurship, topics like Cash book, NonTrading Organization, Profit, and loss account, prepare one to be a business person, we taught how to control money we call it financial skills. As a student I understand how to manage money, marking budget and how to start a business the same applied to commerce as a subject."

Also when responding to the interview, School Headmaster in School C narrated that,

“ Entrepreneurship education supports students from all socioeconomic upbringings' to think creatively and encourage avant-garde talents and skills. It creates opportunities, ensures social justice, implants confidence, and stimulates the economy. Entrepreneurship education is a lifelong learning process, starting as early as straightforward school and progressing through all levels of education, including adult education unfortunately in our education system we are don' $t$ take it in deep though politician real annoyed this truth their good in preaching what they don't practice unasema fanyeni kazi ama kazi iindelee je tumejenga mifumo bora ya elimu kwa vijana kujiandaa or is just a slogan......."

School Head in School B replied that,

"The world is always in need of good leaders for guidance. The students who are attracted to make a difference will certainly pathway. While learning about entrepreneurship skills at early age, the students tend to integrate new skills and start thinking like a leader. Beneficial especially for women entrepreneurs, the leadership skills will coerce them to create their own identity by justifying the existing gender gap in the corporate world."

During the interview with District Education Officer on the same question based on objective number one, he commented that,

"Our world is changing rapidly no doughty on that, and we are voyaging progressively towards a generation equipped with more technical knowledge and encroachment. The 
future belongs to the innovators and leaders. Our education system needs to adapt accordingly. Basic entrepreneurship programs will emerge as a path-breaker and trend-setter providing quite a beneficial initiative for future generation..."

Based on the question and interview, 95\% agree that, Entrepreneurship education allows students to study and creates an interdisciplinary environment to work and develop in. The network and friendships which develop help students to become better connected once they leave school, and help prepare them for long team success.

\section{CONCLUSION AND RECOMMENDATIONS}

The present findings might help to suggest several courses of action to solve this problem. Based on Objective one which aimed to identify entrepreneurship skills required for employment opportunities created as perceived by teachers to students, it was observed that Entrepreneurship Education is a very crucial subject that prepares students to be a global citizens. The benefit of Entrepreneurships includes promoting creativity; enhancing unity and cooperation and employment opportunities. It should be taught as a separate subject hence it gives essential life skills such as an innovative approach to solving real-world problems, life skills as a topic in civics if the fundamental topic to be taught as a subject.

The study recommends that teaching entrepreneurship has to move beyond listing strategies for raising capital, students need also to be equipped with skills enabling them to deal with negative attitudes, competition from cheap imports, choice of appropriate technologies, and to take advantage of other unique factors. There is a distinguished need to improve training programs in Tanzania; there is also a need to develop entrepreneurs who would be able to navigate in local troubled waters. Generally, Entrepreneurship Education to students proved to be good and important in learning some basics. Entrepreneurship education provides students with the ability to get more useful information, to connect with learning groups and other educational systems that make education convenient.

\section{REFERENCES}

[1] Agumuno (2002) Entrepreneurship Education and new venture creation: a comprehensive approach

[2] Aldrich, H.E. (2005) “ Entrepreneurship.” In Handbook of Economic Sociology, N. Smelser and R. Swedberg (eds.), 451-477. Princeton, NJ: Princeton University Press.
[3] Al-Samarrai, $S$ and $T$ Peasgood (1998). Educational attainments and household characteristics in Tanzania, Economics of Education Review, 17(4): 395-417.

[4] Arogundade, and Babatope B (2011). Entrepreneurship Education: An Imperative For Sustainable Development in Nigeria.

[5] Ary, D et al (2010). Introduction to research in education, ( $8^{\text {th }}$ ed). Australia: Wardsworth Engage learning.

[6] Bellis, I (1997). ' Outcomes and competence: Issues of definition and context in curriculum Delivery. A paper presented at the annual SAALA conference, University of Witwatersrand, pp.9-11.

[7] Brock-Utne, B (2002). A short presentation of the LOITASA-a research project with NUFU Funding. EDUCATION, year 6, 1, 2.

[8] Chen, Huey-tsyh. (1990). Theory-driven evaluations. London: Sage Publications.

[9] ChirakaMuhura (2013). Entrepreneurship Education the Road to sustainable development in Tanzania, Hakielimu.

[10] Chinonye Love Moses (2013). Knowledge Management as a Strategy for Achieving High Entrepreneurial Performance and Competitiveness, African Journal of Education, Science, and Technology. University of Eldoret, Kenyan, Vol.:1 No.2, Pp.118-127.

[11] Creswell, J. W. (2012). Educational Research: Planning, Conducting, and Evaluating Quantitative and Qualitative Research (4 th Edition). Boston, Pearson Education, Inc.

[12] Cohen, L. M et al (2005). Research methods in education, ( $5^{\text {th }}$ ed). London: Taylor \& Francis Contextual enablers and hindrances. European Journal of Scientific Research, 76(3), 386.

[13] Denzin, N.K (1997). “ Triangulation in educational research" in Cohen, L. M et al (2005). E-library Institute of Open Learning.

[14] European Commission/EACEA/Eurydice, (2016). Entrepreneurship Education at School in Europe. Eurydice Report. Luxembourg: Publications Office of the European Union.

[15] European Commission/ EACEA/ Eurydice (2016) entrepreneurship Education at School in Europe. Eurydice Report. Luxembourg: Publications Office of the European Union.

[16] Gibb, A. (2005). Entrepreneurship and enterprise education in schools and colleges: insights from UK practice. International Journal of Entrepreneurship Education, 6, 48.

[17] Gilbert K. M. Tietaah, Abena A. Yeboah-Banin, Sarah Akrofi-Quarcoo, Fidelis Y. Sesenu. (2018). Journalism Aid: Country of Origin and Influences on Beneficiary Perceptions and Practices. African Journalism Studies 39:2, pages 90-103.

[18] Kaijage. E and Wheeler's (2013). Supporting Entrepreneurship Education in East Africa, University Nairobi School of Business Kenya.

[19] Kalimasi, P. (2018). Assessment of Entrepreneurship Education Trends in the Formal Education.

[20] Krishna swami, O. R (2009) Methodology of Research in Social Sciences. Mumbai. Himalaya Publishing House. 
[21] Kombo, D. K., \& Tromp, D. L. (2006). Proposal and thesis writing. An introduction to Nairobi: Pauline publications Africa.

[22] Kothari C. R (2004). Research Methodology “Methods and techniques 2nd Ed New age International (P) LTD, Publishers Ranch.

[23] Koul, L. (2005). Methodology of educational research. $\left(4^{\text {th }}\right.$ ed.). New Delhi: Vikas.

[24] Kuratko, D. F. (2015). The Emergence of Entrepreneurship Education: Development, Trends, and Challenges. Entrepreneurship Theory and Practice, 29(5), 577-597. https://doi.org/10.1111/j.1540- 6520.2005.00099.x.

[25] Msoka Elizabeth M (2013) Do Entrepreneurship Skills Have an Influence on the Performance of Women-Owned Enterprises in Africa?.

[26] Msoka Elizabeth M (2013) Do Entrepreneurship Skills Have an Influence on the Performance of Women-Owned Enterprises in Africa?

[27] Müller, H S, Langevang T, and S Jeppesen (1015). Entrepreneurship Development in Africa, Copenhagen Business school.

[28] Muhura (2013). Entrepreneurship Education the Road to sustainable development in Tanzania, Hakielimu.

[29] Mwasalwiba, E., Dahles, H. \&Wakkee, I.A.M. (2012). Graduate entrepreneurship in Tanzania:

[30] Nsubuga, E. H. K (2000). Fundamentals of educational research. Kampala: MK Publishers Administrator. Social and Behavioural Science, vol. 9, no. 7, pp. 671-679.

[31] Njorege, C.W \&Gathungu, J.M (2013). The effect of Entrepreneurship Education and Training on development of small and medium enterprises in Githunguri District Kenya International Journal of Education and Research 1 (8), 1-22.

[32] Ogula, P. A (1998) A Hand Book On Education Research. Nairobi. New Kermit Publishers.

[33] Orodho, A.S., \& Kombo, D.K (2002). Research methods. Nairobi: Kenyatta University. Research Methods in education, ( $\left.5^{\text {th }} \mathrm{ed}\right)$. London: Taylor \& Francis e-library.

[34] Riziki N, and Nuru K et al, (2015). Effect of Entrepreneurship Education on the Entrepreneurial Behavior: The Case of Graduates in the Higher Learning Institutions in Tanzania, Asian Journal of Business Management 7(2): 37-42, 2015.

[35] Robert Hurdson (2013). Entrepreneurship Education: Progression Model. Odense C, Denmark: The Danish Foundation for Entrepreneurship - Young Enterprise. Statistical Abstract (2013), National Bureau of Statistics,

[36] Tanzania Ministry of Finance, July 2014, accessed 22 October 2014 System in Tanzania. Business Management Review, 21(2), 53-65.

[37] The united republic of Tanzania (2004), Education and Training policy,

1. Ministry of Education and Culture.

[38] The united republic of Tanzania (2007). National Youth Development Policy, Ministry of Labor, Employment, and youth development policy.

[39] Saunders, M. Lewis P, and Thorn hill A, (2009).Research Methods for Business Student. Pearson Education Limited. Mugenda, O. M \&Mugenda, A. G (2003).Research
methods:Quantitative and Qualitative Approaches (2 ${ }^{\text {nd }}$ ed.). Nairobi: ACTS PRESS.

[40] The united republic of Tanzania (2014), Education and Training Policy, Ministry of Education and vocation training. Tracy Bailey, Nico Cloete, and PundyPillay,(20)Universities and Economic Development in Africa.

[41] Ujwary, A and Klincewicz, G, (2015). Entrepreneurship: Intentions, Institutions, and Processes, Journal of Entrepreneurship, management, and innovation (JEMI). Volume 11 issue 2.

[42] Ulla Hytti, programs may, (2004) "What is "enterprise education"? An analysis of the Objectives and methods of enterprise education programmes in four European countries", Education + Training, Vol. 46 Issue: 1, pp.11-23.

[43] United Republic of Tanzania (2014).National Education and Training Policy, Ministry of Education Science and Technology, Dar es Salaam.

[44] United Republic of Tanzania (2016) Mtaalawa Elimuya Msingi, Darasa la III-VI, Taasisiya Elimu Tanzania, Dar es Salaam Kalimasi, P. 65.

[45] United Republic of Tanzania (1995). Education and Training Policy, Ministry of Education and Culture, Dar es Salaam.

[46] United Republic of Tanzania (1999). National higher education policy, Ministry of Science Technology and Higher Education, Dar es Salaam.

[47] United Republic of Tanzania (2002). Small and medium enterprises development policy, Ministry of Industry and Trade, Dar es Salaam.

[48] United Republic of Tanzania (2004). National economic empowerment policy, Prime Minister' s Office, Dar es Salaam.

[49] United Republic of Tanzania (2008). National employment policy, Ministry of Labour, Employment and Youth Development, Dar es Salaam.

[50] United Republic Tanzania (2005) Muhutasari wa somo la stadi za kazi kwa shule za msingi darasa la I-VII, Taasisi ya Elimu Tanzania, Dar es Salaam.

[51] Clement V. (2016), Guidelines for Entrepreneurship Education Ministry of Education European Commission / EACEA/ Eurydice, Entrepreneurship Education at school in Europe.

[52] Yagoub A. (2013), The Need for Entrepreneurship Education to achieve MDGs in developing Countries: the case of Sudan (2007).

[53] Yahya U. (2014) why we set entrepreneurship studies in varsities-Federal Government. Retrieved from http://www.thengeriavoice.com/nvnews/45849/1/why-weset-up--entrepreneurship-studies-in-varsities.htldesk page 51 effect of entrepreneurship for self-employment.

[54] Zhou. M and Brown .M (2004) Educational Learning Theories Creative Commons Attribution 